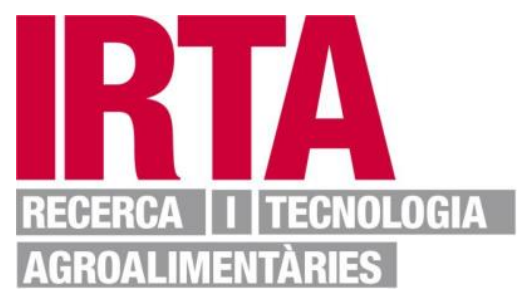

This is the peer reviewed version of the following article: Moura Pereira, Mayara, Mariana Machado Evangelista, Enric Gisbert, and Elizabeth Romagosa. 2019. "Nile Tilapia Broodfish Fed High-Protein Diets: Digestive Enzymes In Eggs And Larvae". Aquaculture Research 50 (8): 2181-2190. Wiley. doi:10.1111/are.14098., which has been published in final form at https://doi.org/10.1111/are.14098. This article may be used for non-commercial purposes in accordance with Wiley Terms and Conditions for Use of Self-Archived Versions http://www.wileyauthors.com/selfarchiving.

Document downloaded from: 


\title{
NILE TILAPIA BROODFISH FED HIGH-PROTEIN DIETS: DIGESTIVE ENZYMES IN EGGS AND LARVAE
}

Mayara de Moura Pereira $^{\mathrm{a}^{*}}$, Mariana Machado Evangelista ${ }^{\mathrm{a}}$, Enric Gisbert ${ }^{\mathrm{c}}$, Elizabeth Romagosa $^{\mathrm{d}}$

aAquaculture Center Unesp (CAUNESP), Via de Acesso Professor Paulo Donato Castellano, km 5, Jaboticabal, São Paulo, 14884-900, Brazil

${ }^{\mathrm{b}}$ Fishery Institute, APTA, Rodovia Washington Luiz, km 445, Zona Rural, São José do Rio Preto, São Paulo, 15025-970, Brazil

c IRTA, Centre de Sant Carles de la Ràpita, Programa d'Aqüicultura, Crta de Poblenou km 5.5, 43450 Sant Carles de La Ràpita, Tarragona, Spain

d Fishery Institute, APTA, Avenida Francisco Matarazzo, 455, Água Branca, São Paulo, 05001000, Brazil

*Corresponding author: Tel.+55 (17) 99142-0910, e-mail address: maaqui09@gmail.com

Running head: Nile tilapia broodfish: enzymes in eggs and larvae

\begin{abstract}
The aim of this study was to assess the activity of gastric, pancreatic and intestinal digestive enzymes during the embryonic and larval development of Nile tilapia (Oreochromis niloticus) GIFT strain Aqua America ${ }^{\circledR} 1$ obtained from a broodstock fed two levels of crude protein (CP). A total of 72 females and 24 males, 10 hapas, two CP levels (32\% and 38\%) and six phases of embryonic (cleavage, blastula, gastrula) and larval (hatching, 7 and 10 days post hatch, dph) stages were used. The eggs were collected in cleavage, blastula and gastrula stages, $300 \mathrm{mg}$ was collected, and kept in cryogenic tubes in liquid nitrogen. For the samples at larval stage, the remaining eggs were separated according to crude protein level and kept in hatcheries and samples were collected on 7 and $10 \mathrm{dph}$ the same way as before. A total of 48 samples were collected: at each protein level (32\% and $38 \% \mathrm{CP}$ ), four samples were collected in each phase of embryonic and larval development. Statistical differences were not ob - served during embryonic development for acid proteases, trypsin, amylase and lipase activity at both levels of crude protein (32 and 38\% CP). Differences for acid pro - teases were noticed on $7 \mathrm{dph}$; trypsin and amylase on $7 \mathrm{dph}$ and $10 \mathrm{dph}$. Significant differences on blastula and $7 \mathrm{dph}$ for protease; as for aminopeptidase, there was significant difference on $7 \mathrm{dph}$. The data indicated early appearance of digestive en - zymes in Nile tilapia broodfish receiving $32 \% \mathrm{CP}$ taking into account the rapid growth and development of this species.
\end{abstract}


Keywords: cichlids, digestive physiology, nutrition, ontogeny, reproduction

\section{Introduction}

Nile tilapia, Oreochromis niloticus is one of the most commonly cultured fish species in Brazil (468,932 tn in 2016) and worldwide (5,896,813 th in 2016) according to FAO - FIGIS (2019)). Due to the fast growth and good adaptation to intensive culture conditions of this cichlid species, fish farming has been intensified, creating the need for new rearing techniques that could make the process more efficient and viable (EMBRAPA, 2013). Furthermore, in the last few years considerable progress has been made in the knowledge of the nutritional demands of Nile tilapia, but there is still a need for further studies on nutrition that consider different categories of weight or age, as well as specific studies about broodfish (Furuya, Barros, Pezzato, \& Cyrino, 2013), because this species is considered an important fish produced worldwide (Oliveira et al., 2015, 2014). In this context, it is known that fish feeding is fundamental and is responsible for over $60 \%$ of the total cost of fish farming (Teixeira et al., 2008). Therefore, diets should be developed in order to meet the requirements of the fish at different stages of development (larvae, juvenile and adult). The biochemical composition of brood stock diets is one of the key determinants of the eggs, biochemical composition that influences the success of reproduction, as well as the offspring survival, since it provides the necessary nutrients for embryonic development and the lecithotrophic larval period (Izquierdo, Fernández - Palacios, \& Tacon, 2001). Eggs represent a substantial energy investment that depends mainly on maternal contribution, since they are responsible for the synthesis of the yolk sac and other substances for the development of the zygote until it can be independent, receiving exogenous feeding, indispensable to the larvae (Brooks, Tyler, \& Sumpter, 1997). Egg quality can be affected by intrinsic factors (parental genetics, reproductive age, yolk sac composition) or extrinsic factors (reproductive period, breeders manipulation, reproductive diet and water quality) (Mylonas \& Zohar, 2007). In order to meet those requirements, so that nutrients can be absorbed and made available to the animal's organism, the action of digestive enzymes is necessary (Gisbert, Gimenez, Fernandez, Kotzamanis, \& Estevez, 2009). That process varies according to the catalytic role of the enzymes and will allow the use of those nutrients (Baldisserotto, Cyrino, \& Urbinati, 2014). In general, digestive enzymes reflect the characteristics of the digestive system of the fish and directly influence the capacity to digest and absorb the food (Gao, Luo, \& Cao, 2006), depending on the amount, specificity and adequate conditions ( $\mathrm{pH}$ and temperature) for the reaction of those enzymes (Kuz' mina, 1996). Thus, those enzymes are used to evaluate the nutritional condition at any stage of embryonic (Tong, Xu, \& Liu, 2013), larval (Cara, Moyano, 
Zambonino Infante, \& Fauvel, 2007; Pradhan, Jena, Mitra, Soad, \& Gisbert, 2013) and juvenile (Asgari et al.., 2013) development of the fish.

The present study aimed to assess the activity of gastric (acid proteases), pancreatic (trypsin, amylase, lipase, protease) and intestinal (aminopeptidase and alkaline phosphatase) digestive enzymes during embryonic (cleavage, blastula and gastrula) and larval (hatching, 7 and 10 days post hatch) development in Nile tilapia, O. niloticus GIFT strain Aqua America ${ }^{\circledR}$ 1, obtained from broodstock fed diets with two levels of crude protein (32 and 38\%).

\section{Material and Methods}

\section{Experimental design, fish and diets}

The Nile tilapia broodstock GIFT strain Aqua America ${ }^{\circledR} 1$ used in the present trial was acquired from the Peixe Vivo ${ }^{\circledR}$ Fish farm, located in Santa Fé do Sul - São Paulo (Brazil). The experiment was carried out at Agência Paulista de Tecnologia dos Agronegócios (APTA) - Research and Development Unit (UPD) in the town of Pirassununga, São Paulo, Brazil (21 55 '37,4" S 47²2'10" $\mathrm{O})$.

A completely randomized design was used with a factorial scheme with two levels of crude protein (32\% and 38\% of crude protein, CP) and six phases of embryonic (cleavage, blastula, gastrula) and larval (hatching, $7 \mathrm{dph}$ and $10 \mathrm{dph}$ ) development. Experimental diets (Tables 1 and 2) were formulated and manufactured at the Fishery Institute, APTA, in São José do Rio Preto, São Paulo (Brazil). Raw materials were weighed, homogenized, grounded $(0.7 \mathrm{~mm})$, extruded in 4.0 mm pellets (Ferraz E- $62^{\circledR}$ extruder) and dried in a forced ventilation oven at $55.0^{\circ} \mathrm{C}$ for 24 hours. Feed was sealed in plastic bags and conserved at $4{ }^{\circ} \mathrm{C}$ until further use. Experimetnal diets were offered twice a day $(9: 00$ am and 4:00 pm) at a feeding daily ratio of $1 \%$ of the stocked biomass.

Ninety-six Nile tilapia broodstock GIFT strain were used: seventy-two females $(280.30 \pm$ $69.60 \mathrm{~g})$ and twenty-four males $(372.5 \pm 110.68 \mathrm{~g})$ with six months of age ( $1^{\text {st }}$ gonad maturation $)$. The broodfish were first electronically identified with microchips (AnimalTAG®). The experiment was conducted in an earthen pond $\left(200 \mathrm{~m}^{2} \times 1.5 \mathrm{~m}\right.$ deep $)$ where ten hapas $(3.0 \times 1.5 \times 1.5 \mathrm{~m})$ were placed for experimental purposes. In particular, eight hapas, 4 hapas per experimental diet, were used for assessing the reproductive performance of brooders (sex ratio: 3 males and 9 females per hapa), whereas the remaining two were used to keep males separated from females after each reproductive event (recovery hapas). Before the beginning of the reproductive period, breeders from each treatment were fed with the respective diets for a period of 30 days, as well as throughout the whole experimental period. 
During the experiment (150 days), eggs were collected every seven days. After egg collection, brooders (males and females) were separated into different hapas in order to allow them to better recover from the reproduction stage. Males and females remained separated for 15 days, when the males were taken to auxiliary hapas (recovery phase). During the recovery period, all fish were fed with the same experimental diet and under the same feeding practices. After 15 days, males were taken from recovery hapas and brought back to their respective reproductive hapas (for another period of 7 days of reproductive activity. The above-mentioned procedure was repeated five times over the 150-days experimental period in order to collect enough biological samples necessary for analytical purposes.

During the experiment (150 days), eggs were collected every 7 days. After egg collection, brooders (males and females) were sep - arated into different hapas in order to allow them to better recover from the reproduction stage. Males and females remained separated for 15 days, when the males were taken to auxiliary hapas (recovery phase). During the recovery period, all fish were fed the same ex - perimental diet and under the same feeding practices. After 15 days, males were taken from recovery hapas and brought back to their respective reproductive hapas for another period of 7 days of re - productive activity. The above - mentioned procedure was repeated five times over the 150 - day experimental period in order to collect enough biological samples necessary for analytical purposes.

During the reproductive period the mean values of water temperature were $28.0 \pm 1.67^{\circ} \mathrm{C}$, oxygen levels $5.8 \pm 0.44 \mathrm{mg} / \mathrm{L}$ and $\mathrm{pH} 6.70 \pm 0.42$. Females were individually inspected by using a hand net and a microchip scanner, so that the presence of eggs in the oropharyngeal cavity could be detected. These procedures were conducted according to the methodology described by Lupatsch, Deshev, and Magen (2010). Eggs were removed from the female's buccal cavity with a wash bottle and water from the pond and then, taken to the laboratory so that the stage of embryonic development could be ob - served with the aid of a stereomicroscope with an integrated digital camera (BEL - 40X). Embryonic stages (cleavage, blastula and gastrula were identified according to (Fujimura \& Okada, 2007), and samples of ca. $300 \mathrm{mg}$ were collected, kept in cryogenic tubes and placed in liquid nitrogen $\left(-196.0^{\circ} \mathrm{C}\right)$ for further analysis. Regarding sample collection during the larval stage, the remaining eggs were separated according to their respective dietary treatment and kept in incubation jars $(400 \mathrm{ml})$ with water recirculation and control of the physical and chemical variables until they hatched (temperature $28.00 \pm 1.00^{\circ} \mathrm{C} ; \mathrm{pH}-6.48 \pm 0.25$ and oxygen levels $-6.1 \pm 0.35 \mathrm{mg} / \mathrm{L})$. At hatching, samples of newly hatched larvae (300 mg) were collected and kept in liquid nitrogen as described above. Similarly, fasted larvae were collected at 7 and 10 days post hatch and frozen until their further analysis for assessing the activity of gastric, pancreatic 
and intestinal digestive enzymes. A total of fortyeight samples were collected for each dietary broodstock protein level (32\% and 38\% CP). In particular, four samples were collected in each stage of embryonic (cleavage, blastula and gastrula) and larval (hatching, 7 and $10 \mathrm{dph}$ ) development. The reproductive parameters of the females used in this experiment were evaluated by Ribeiro et al. (2018).

\section{Analysis of digestive enzymes}

The analysis of enzyme activity of the Nile tilapia eggs and larvae was conducted at IRTA in Sant Carles de la Ràpita (Spain). In order to determine the activity acid and alkaline proteases, as well of $\alpha$-amylase and lipase enzymes at the three initial stages (cleavage, blastula and gastrula), samples were homogenized (Ultra-Turrax T25 basic, IKAC), Germany) in 5 volumes of ice-cold milli-Q water $\left(4.0^{\circ} \mathrm{C}\right)$, centrifuged at $3300 \mathrm{xg}$ for $3 \mathrm{~min}$ at $4.0^{\circ} \mathrm{C}$, and then aliquots of supernatant were removed and kept at $-80.0^{\circ} \mathrm{C}$ for later quantification following the recommendations of Solovyev and Gisbert (2017).

At larval stages (hatching, 7 and $10 \mathrm{dph}$ ), the above-mentioned gastric and pancreatic enzymes were also analyzed in addition to intestinal ones, such as aminopeptidase and alkaline phosphatase.. Larval samples were homogenized in $50.0 \mathrm{mM}$ mannitol at $4.0{ }^{\circ} \mathrm{C}, 2.0 \mathrm{mM}$ Tris- $\mathrm{HCl}$ buffer $(\mathrm{pH}$ 7.0). An aliquot of the supernatant $(1.0 \mathrm{~mL})$ was placed in a microtube and stored at $-20.0^{\circ} \mathrm{C}$ for gastric and pancreatic enzyme quantification, whereas the rest of it was kept for purification brush border enzymes (Gisbert et al., 2018). In brief, the supernatant was centrifuged twice, $9000 \mathrm{xg}$ for $10 \mathrm{~min}$ at $4.0^{\circ} \mathrm{C}$, and then at $23,929 \mathrm{x} \mathrm{g}$, for $25 \mathrm{~min}$ at $4.0^{\circ} \mathrm{C}$, respectively, and the brush border (pellet) dissolved in a buffer of Tris $(2 \mathrm{mM})$ - mannitol $(50 \mathrm{mM})$.

Acid proteases and pepsin (E.C.3.4.23.1) were quantified at $30.0{ }^{\circ} \mathrm{C}$ using $2 \%$ hemoglobin as substrate in $1 \mathrm{~N} \mathrm{HCl}$ buffer. Pepsin activity (U) was defined as $\mu \mathrm{mol}$ of hemoglobin released per minute at $30.0^{\circ} \mathrm{C}$ per $\mathrm{mL}$ of crude enzyme homogenate at $\lambda=280 \mathrm{~nm}$ (Worthington, 1972). Aminopeptidase (E.C.3.4.11.2) activity was determined according to Maroux et al. (1973) at 30.0 ${ }^{\circ} \mathrm{C}$, using $80.0 \mathrm{mM}$ sodium phosphate buffer solution $(\mathrm{pH}=7.0)$ and L-leucine p-nitroanilide as substrate dissolved in $0.1 \mathrm{mM}$ DMSO. One unit of enzyme activity (U) was defined as $1.0 \mu \mathrm{g}$ nitroanilide released per minute per $\mathrm{mL}$ of brush border homogenate at $\lambda=410 \mathrm{~nm}$. Alkaline phosphatase (E.C.3.1.3.1) was quantified at $30.0{ }^{\circ} \mathrm{C}$, using 4-nitrophenyl phosphate (PNPP) as substrate in $30.0 \mathrm{mM} \mathrm{Na}_{2} \mathrm{CO}_{3}$ buffer $(\mathrm{pH}=9.8)$. One unit $(\mathrm{U})$ was defined as $1.0 \mu \mathrm{g}$ PNPP released per minute per $\mathrm{mL}$ of brush border homogenate at $\lambda=407 \mathrm{~nm}$ (Bessey et al., 1946). Trypsin (E.C.3.4.21.4) was analyzed at $30.0^{\circ} \mathrm{C}$ using BAPNA ( $\mathrm{N}-\alpha$ - benzoyl-dl-arginine p-nitroanilide) as substrate in $50.0 \mathrm{mM}$ Tris- $\mathrm{HCl}, 20.0 \mathrm{mM} \mathrm{CaCl}_{2}$ buffer $(\mathrm{pH}=8.2)$. One unit of trypsin per $\mathrm{mL}(\mathrm{U})$ was defined as $1 \mu$ mol BAPNA hydrolyzed per min per mL of enzyme extract at $\lambda=407 \mathrm{~nm}$ (Gisbert 
et al., 2009). Amylase activity (E.C.3.2.1.1) was measured according to Métais \& Bieth (1968), using $0.3 \%$ soluble starch as substrate dissolved in $\mathrm{Na}_{2} \mathrm{HPO}_{4}$ buffer $(\mathrm{pH}=7.4)$. Alpha-amylase activity $(\mathrm{U})$ was defined as the $\mathrm{mg}$ of starch hydrolyzed during $30 \mathrm{~min}$ per $\mathrm{mL}$ of tissue homogenate at $30.0^{\circ} \mathrm{C}$ at $\lambda=580 \mathrm{~nm}$. Lipase activity (E.C.3.1.1) was assessed for $30 \mathrm{~min}$ at $30.0^{\circ} \mathrm{C}$ using pnitrophenyl myristate as substrate, dissolved in $0.25 \mathrm{mM}$ Tris- $\mathrm{HCl}, 0.25 \mathrm{mM}$ 2- methoxyethanol and $5 \mathrm{mM}$ sodium cholate buffer $(\mathrm{pH}=9.0)$. The reaction was interrupted with a solution of acetone: $\mathrm{n}$ - heptane (5:2); the homogenate was centrifuged for 2 minutes at $6,080 \mathrm{xg}$, at $4.0^{\circ} \mathrm{C}$ and read at $\lambda$ $=405 \mathrm{~nm}$. Lipase activity $(\mathrm{U} / \mathrm{mL})$ was defined as the $\mu \mathrm{mol}$ of substrate hydrolyzed per minute per mL of enzyme extract (Iijima et al., 1998). Total alkaline protease activity (E.C.3.4) was quantified at $30.0^{\circ} \mathrm{C}$ using $0.5 \%$ azocasein as substrate in Tris $-\mathrm{HCl} 50 \mathrm{mM}$ buffer $(\mathrm{pH}=8.0)$. The activity (U) was defined as $1.0 \mu \mathrm{mol}$ azocasein hydrolyzed at $30.0{ }^{\circ} \mathrm{C}$ per minute per $\mathrm{mL}$ of homogenate at $\lambda=366 \mathrm{~nm}$ (Hidalgo et al., 1999).

The specific activities were expressed as unit per milligram of protein (U/mg protein). The soluble protein of the crude extract of eggs and larvae samples was quantified according to Bradford's method (Bradford, 1976), using bovine serum albumin as standard. All the assays were made in triplicate. All analyses were conducted with a TECAN ${ }^{\circledR}$ spectrophotometer.

The experimental results were expressed as mean \pm standard deviation (SD) and statistical analyses were performed using STATISTICA 7.0 (Statsoft 2005). The activities of digestive enzymes were compared between different crude protein levels at each stage of embryonic and larval development using a two-way ANOVA, Tukey test and significant differences were made at the 0.05 level.

\section{Results}

The larval weight and length of Nile tilapia is presented in Figure 1. No significant differences were observed for both CP levels to this parameters (larval weight and length), however, was observed that the larvae presented higher weights with breeders feed with $32 \% \mathrm{CP}$ and superior size with $38 \% \mathrm{CP}$. The activity of assayed enzymes during embryonic and larval development is shown in Figure 2. The two- way ANOVA showed a significant interaction between the factors considered in this study (crude protein level and development stage), whereas acid proteases, trypsin, amylase, lipase and alkaline phosphatase activities were higher with $32 \% \mathrm{CP}$, mainly after the hatching phase.

There were no statistical differences in the activities of acid proteases, trypsin, $\alpha$ - amylase and lipase in embryo samples collected at cleavage, blastula and gastrula stages regardless of the levels of crude protein (32 and $38 \% \mathrm{CP}$ ) offered to the Nile tilapia broodfish. However, the increased activity 
of these enzymes after hatching was unequivocal for both experimental groups (Figure $2 ; p<0.05$ ). Regarding acid proteases, there were not statistical significant dif- ferences between both experimental groups at hatching $(p>0.05)$, whereas at $7 \mathrm{dph}$, activity was higher in the offspring from brooders fed $32 \% \mathrm{CP}$ in comparison to the $38 \% \mathrm{CP}$ group. At $10 \mathrm{dph}$, acid protease activity decreased in larvae from the $32 \% \mathrm{CP}$ group and became similar to that measured in larvae from the $38 \% \mathrm{CP}$ group $(p<0.05)$.

Regarding trypsin, significant differences $(\mathrm{p}<0.05)$ were noticed in the activity of trypsin in larvae from broodfish fed different protein levels (32 and 38\%) at $7 \mathrm{dph}$ and $10 \mathrm{dph}$ in comparison to hatching time; however, both of them presented higher activity levels in larvae from broodfish fed the $32 \% \mathrm{CP}$ diet at sampled ages (Figure 2). In addition, trypsin activity in larvae from the $32 \% \mathrm{CP}$ group increased from $7 \mathrm{dph}$ to $10 \mathrm{dph}$, but the activity of this serine protease remained stable between 7 and $10 \mathrm{dph}$ in larvae from the $38 \% \mathrm{CP}$ group. Alpha-amylase increased from hatching to $7 \mathrm{dph}$ in both experimental groups $(\mathrm{p}<0.05)$, whereas it remained stable between 7 and $10 \mathrm{dph}(\mathrm{p}>$ $0.05)$. Similarly to trypsin, activity of $\alpha$ - amylase was higher in larvae from the $32 \% \mathrm{CP}$ group in comparison to those from the $38 \% \mathrm{CP}$ group $(\mathrm{p}<0.05)$. Lipase showed a similar trend than amylase, although no differences in activity were found until $10 \mathrm{dph}$ with regard to previous ages. Similarly, $\alpha$-amylase activity at $10 \mathrm{dph}$ was higher in larvae from the $32 \% \mathrm{CP}$ group in comparison to those from the $38 \%$ CP group ( $\mathrm{p}<0.05)$.

Regarding total alkaline proteases, there was significant increase in the activity of this group of proteolytic enzymes at the blastula stage in both experimental groups, although the majority of increase was higher in embryos from the $32 \% \mathrm{CP}$ group (Figure 3; $p<0.05$ ). At the gastrula stage, total protease activity decreased, whereas at hatching activity increased again $(p<0.05)$ and remained stable in larvae from the $38 \% \mathrm{CP}$ group. In contrast, total alkaline protease activity in larvae from the $32 \% \mathrm{CP}$ group significantly in- creased at $7 \mathrm{dph}$, whereas it decreased again at 10 dph $(p<0.05)$, reaching similar values than those from larvae from the 38\% CP group $(p>0.05)$. Regarding the activity of brush border intestinal enzymes (Figure 3), we observed a significant difference $(p<0.05)$ for amino- peptidase on $7 \mathrm{dph}$; being higher in larvae from the $32 \%$ CP group. Nevertheless, after $7 \mathrm{dph}$, there was a decrease in this enzyme until $10 \mathrm{dph}$. Alkaline phosphatase did not exhibit significant difference $(p>0.05)$ in the larval phases with regard to the levels of protein. Besides, it demonstrated similar activity patterns in the levels of 32 and $38 \% \mathrm{CP}(p>0.05)$.

\section{Discussion}


In fish, digestive enzymes play an important role on yolk sac catabolism (Ohkubo, Sawaguchi, Nomura, Tanaka, \& Matsubara, 2008), energy metabolism and growth regulation during embryonic development (Amalia, Helena, Vera, \& Aires, 2013). Enzymes related to the digestion of proteins, carbohydrates and lipids in fish are present in this study. The activity of acid proteases and alkaline proteases, $\alpha$-amylase and lipase were observed during the phases of embryonic development, and gastric, pancreatic and intestinal enzymes (aminopeptidase and alkaline phosphatase) during the larval period of Nile tilapia. During the embryonic period, acid proteases activity was observed from cleavage. However, the protein levels did not influence the behaviour of this enzyme in the phases of embryonic development (cleavage, blastula and gastrula). Nevertheless, after hatching there was a peak in acid proteases activity until $7 \mathrm{dph}$ for the levels of crude protein; the activity was higher at $32 \% \mathrm{CP}$, suggesting the development of a premature functional stomach and precocity of the species. In other studies with larvae, the proteolytic activity of Sparus aurata was only noticed before mouth opening and beginning of exogenous feeding (Moyano, Diaz, Alarcon, \& Saraqueste, 1996), and with Atractoscion nobilis and Dentex dentex, the differentiation of gastric glands occurred only on $16 \mathrm{dph}$ and $19 \mathrm{dph}$ respectively (Galaviz, Gasca, Drawbridge, Álvarez-Gonzalez, \& Lopez, 2011; Gisbert et al., 2009). On the other hand, some data do not corroborate the present study, since according to LAZO, Mendoza, Holt, Aguilera, and Arnold (2007), acid proteases is not detected during the early stages of larval development, and digestion is performed mainly by alkaline proteases like trypsin.

However, the present study showed that even if acid proteases activity is low, it is present and occurs from the beginning of embryonic development. Nonetheless, proteases has lower activity when compared with trypsin, since trypsin may be of primary importance in the digestion of proteins even before the development of gastric glands (Zambonino-Infante \& Cahu, 2007). Besides, it is the only pancreatic enzyme capable of self - activation, and activating other digestive enzymes as well (Nazemroaya, Yazdanparast, Nematollahi, Farahmand, \& Mirzadeh, 2015). Thus, the present study showed increasing values of trypsin from the cleavage phase until $10 \mathrm{dph}$, when the level of $32 \% \mathrm{CP}$ provided higher values in all the phases, which can be explained by the genetically programmed process (Zambonino - Infante \& Cahu, 2001). In other studies, trypsin activity was detected in embryos of Scophthalmus maximus L during cleavage, blastula, gastrula and hatching (Tong et al., 2013), in larvae of Sparodentes hasta (Nazemroaya et al., 2015) at the moment of hatching, red porgy on 3 dph (Suzer et al., 2007) and sea bass on 4 dph (Zambonino Infante \& Cahu, 1994).

Amylase, a pancreatic enzyme, acts in the anterior portion of the intestine working on the digestion of polysaccharides producing oligosaccharides (Lovell, 1988). In this study, the value of amylase was relatively low during embryogenesis; however, some activity was noticed and there was definitely an increase after hatching, showing statistical difference between both protein levels on 
$7 \mathrm{dph}$ and $10 \mathrm{dph}$, but the lowest level of $32 \% \mathrm{CP}$ showed higher values of this enzyme. Amylase activity present from cleav age may be explained by the idea of genetically programmed secretion of amylase, like trypsin, and not necessarily stimulated during the embryonic phase (Ma et al., 2005). In addition, it is noted that the $32 \%$ CP treatment has higher levels of starch in its composition, being the same that presented higher activities of this enzyme. In disagreement with the present study, experiments with Scophthalmus maximus in the period of embryonic develop ment showed absence of amylase activity, signalizing that for this species carbohydrates are less essential for energy metabolism (Tong et al., 2013). In Sobaity sea bream larvae, the presence of amylase activity after hatching was reported (Nazemroaya et al., 2015), and also for Yellow kingfish (Chen, Qin, Kumar, Hutchinson, \& Clarke, 2006).

Lipase, as well as the previous enzyme, acts in the initial portion of the intestine, hydrolysing triacylglycerols into fatty acids and glyc erol, generating energy for the cell (Nelson \& Cox, 2014). An increase in lipase activity was noticed in the hatching phase. One possible explanation for its presence from the beginning of embryonic development is that in teleost fish, the major yolk components consist of lipoproteins and phosphoproteins (Mommsen \& Walsh, 1988; Oozeki \& Bailey, 1995), which can be verified by the higher values when compared with other pancreatic and gastric enzymes. In addition to the high lipid levels present in the diet of $32 \% \mathrm{CP}$ offered to the breeders, suggesting a greater deposition of lipids in the yolk sac. Furthermore, on $10 \mathrm{dph}$ the level of $32 \% \mathrm{CP}$ provided higher values than $38 \% \mathrm{CP}$, showing better performance of this enzyme. Lipase activity was also reported during hatching, like in Sobaity sea bream, Sparidentex hasta (Nazemroaya et al., 2015) and commom dentex, Dentex dentex (Gisbert et al., 2009).

According to Zambonino-Infante and Cahu (2007), the proteases encompass the enzymes participating in protein digestion, especially the alkaline enzymes, mainly represented by trypsin (pancreas) and aminopeptidase (intestine). Moreover, there are acid proteases, of which acid proteases is the greatest representative. In this context, the present study showed a difference in protease activity during the blastula and $7 \mathrm{dph}$ phases, and the level of $38 \% \mathrm{CP}$ was numerically higher than the $32 \% \mathrm{CP}$ level, suggesting that the amount of protein offered interfered with the activity of this enzyme. The peaks of protease activity in these specific phases can be explained by the fact that this blastula phase is the time when there is greater multiplication of the cells and the treatment with $38 \%$ offered more protein, which may have caused greater deposition in the vitelline sac and increased the activity of the same. The high activity of protease at $7 \mathrm{dph}$ may be related to the end of yolk sac absorption, which, according to Godinho, Santos, and Sato (2003) is the period in which the digestive system is still in differentiation, that is, progressive appearance of organs of the digestive system, corroborating the reports of Martinez, Moyano, Fernandez Diaz, and Yufera (1999) studying Sonegal sole, Solea sonegalensis. 
With the maturation of the digestive tract of fish larvae, the intestinal villi increase (number and size) and the presence of vacuoles found in the enterocytes are intensified, because of the dif ferent absorptive regions (Portella, Leitão, Takata, \& Lopes, 2013). Aminopeptidase activity peaked on 7 dph with $38 \% \mathrm{CP}$, which may be explained by the fact that this enzyme is involved in the absorption and transport of proteins, and that level (38\% CP) caused significant increase in aminopeptidase activity.

In general, in fish, alkaline phosphatase acts on intestinal villi (Lojda, Gossrau, \& Schiebler, 1979) the same way as aminopeptidase; it is, however, directly involved in the absorption and transport of lipids and carbohydrates (Guillaume \& Choubert, 2001). It was verified that the levels of crude protein (32 and 38\%) in the diet of Nile tilapia broodfish did not influence the behaviour of this enzyme. Nonetheless, an increase in alkaline phosphatase activity was observed after hatching until $10 \mathrm{dph}$, and according to Tong et al. (2017), the activity of this enzyme grows because it may be related to the formation and differentiation of primordial tissues. Jimenez-Martinez et al., (2012), studying alkaline phosphatase activity in common snook verified increase only 3 weeks after hatching, which shows how fast the intestinal development and growth of Nile tilapia are. That can also be observed in sobaity sea bream (Nazemroaya et al., 2015), where the authors observed alkaline phosphatase activity on $5 \mathrm{dph}$, corroborating the present study with regard to how early this enzyme starts to act.

According to Lupatsch et al. (2010), most of the nutrients consumed by the breeders are directed to development of gonads, eggs and growth of fish larvae. In this way, it was considered that the level of $32 \% \mathrm{CP}$ presented numerically satisfactory values for enzymatic activities in embryonic development and larval phase, beyond the amount required for reproduction of Nile tilapia, once, the female reproductive parameters used in this study indicated that the num - ber, weight and volume of eggs did not show significant differences between levels of 32 and 38\% CP (Ribeiro et al., 2018). In addition, also have not been noted differences to the diameter of the eggs, absolute fecundity and the number of females that spawned.

In short, our data indicated the early appearance of gastric, pancreatic and intestinal enzymes in Nile tilapia broodfish when they received $32 \% \mathrm{CP}$, which showed the best results, suggesting rapid development and growth of this species. Furthermore, it was demonstrated that the level of $32 \%$ $\mathrm{CP}$ is enough for Nile tilapia broodfish, with better performance of digestive enzymes. However, other studies should be conducted for further information about supplementation of ideal levels of crude protein in diets for Nile tilapia broodfish.

\section{ACKNOWLEDGMENTS}


The authors thank Leonardo Tachibana, Maria José T. Ranzani - Paiva, Danielle de Carla Dias

- Fishery Institute, APTA, SP, Brazil and Fabio Rosa Sussel APTA, UPD, Pirassununga, SP for their col - laboration. Special thanks to Marta Sastre for the help during lab - oratory analysis in the IRTA, Spain. The funding was provided by Fundação de Amparo à Pesquisa do Estado de São Paulo - FAPESP (nº 2013/24474-1; 2013/22570-3 and BEPE 2014/15194-8).

\section{DATA AVAIL ABILIT Y}

The data in this article have not been published previously. However, these data are part of my master's thesis that is in the postgraduate file that I studied in the master's degree. The following link is where my dissertation is: http://www.athena.biblioteca.unesp.br/exlibris/ bd/cathedra/1407-2016/000866510.pdf. This way, the data were not previously shared.

\section{REFERENCE S}

Amalia, P.-J., Helena, P., Vera, C.R., \& Aires, O.-T. (2013). Effects of diet supplementation with white tea and methionine on lipid metabolism of gilthead sea bream juveniles (Sparus aurata). Fish Physiology and Biochemistry. 39, 661-670.

Asgari, R., Rafiee, G., Eagderi, S., Noori, F., AGH, N., Poorbagher, H., \& Gisbert, E. (2013). Ontogeny of the digestive enzyme activities in hatchery produced beluga (huso huso). Aquaculture, 416-417, 33-40. http://doi.org/10.1016/j.aquaculture.2013.08.014

Baldisserotto, B., Cyrino, J.E.P., \& Urbinati, E.C. (2014). Biologia e fisiologia de peixes neotropicais de água doce, Jaboticabal, São Paulo, brasil.

Bessey, O.A., Lowry, O.H., \& Brock, M.J. (1946). Rapid coloric method for determination of alkaline phosphatase in five cubic millimeters of serum. Journal Biology Chemistry, 164, 321-329.

Bradford, M. (1976). A rapid and sensitive method for the quantitation of microgram quantities of protein using the principle of protein dye binding. Analytical Biochemistry, 72, 248-254. 
Brooks, S., Tyler, C.R., Sumpter, J.P. (1997). Egg quality in fish: what makes a good egg? Reviews in Fish Biology and Fisheries, 7, 387-416.

Cara, B., Moyano, F.J., Zambonino Infante, J.L., Fauvel, C. (2007). Trypsin and chymotrypsin as indicators of nutritional status of post-weaned sea bass larvae. Journal of Fish Biology. 70, 17981808.

Chen, B.N., Qin, J.G., Kumar, M.S., Hutchinson, W., \& Clarke, S. (2006). Ontogenetic development of the digestive system in yellowtail kingfish (Seriola lalandi) larvae. Aquaculture 256, 489-501.

Crane, R.K., Boge, G., \& A. Rigal. (1979). Isolation of brush border membranes in vesicular form from the intestinal spiral valve of the small dog fish Sayliorhinus canicula. Biochemistry Biophysiology Acta, 554, 264-267.

EMBRAPA. (2013). Piscicultura de água doce: multiplicando conhecimentos, Palmas, Brazil.

Fujimura, K. \& Okada, N. (2007). Development of the embryo, larva and early juvenile of Nile tilapia Oreochromis niloticus (pisces: cichlidae). Development Growth Differentiation, 49, 301-324. http://doi.org/10.1111/J.1440-169X.2007.00926.X

Furuya, W.M., Barros, M.M., Pezzato, L.E., \& Cyrino, J.E.P. (2013). Exigências nutricionais e alimentação da tilápia. in: fracalossi, d.m.; cyrino, j.e.p. (eds). Nutrição e Alimentação de Espécies de Interesse para a Aquicultura Brasileira. Editora Copiart 1tda, Florianópolis, SC, Brasil. p.167179.

Galaviz, M.A., Gasca, A.G., Drawbridge, M., Álvarez-González, C.A., \& López, L.M. (2011). Ontogeny of the digestive tract and enzymatic activity in white seabass, Atractoscion Nobilis, larvae. Aquaculture, 318, 162-168. http://doi.org/10.1016/j.aquaculture.2011.05.014

Gao, M., Luo, Y.P. \& Cao, Z.D. (2006). Effect of dietary carbohydrate on digestive enzyme activities in southern catfish (Silurus meridionalis chen) juveniles. Journal of South West China Normal University (National Science), 31, 119-123. 
Gisbert, E., Gimenez, G., Fernandez, I., Kotzamanis, Y., \& Estevez, A. (2009). Development of digestive enzymes in common dentex, Dentex dentex during early ontogeny. Aquaculture, 287, 381387. http://doi.org/10.1016/j.aquaculture.2008.10.039

Gisbert, E., Nolasco, H., \& Solovyev, M. (2018). Towards the standardization of brush border purification and intestinal alkaline phosphatase quantification in fish with notes on other digestive enzymes. Aquaculture, 487, 102-108.

Guillaume, J. \& Choubert, G. (2001). Digestive physiology and nutrient digestibility in fishes. in nutrition and feeding of fish and crustaceans. Chichester, United Kingdon, 27-58.

Hidalgo, M.C., Urea, E. \& Sanz, A. (1999). Comparative study of digestive enzymes in fish with different nutritional habits. Proteolytic and amylase activities. Aquaculture, 170, 267-283.

Iijima, N., Tanaka, S., \& Ota, Y. (1998). Purification and characterization of bile-salt activated lipase from the hepato pâncreas of red seabream, Pagrus major. Fish Physiology and Biochemistry, 18, $59-69$.

Izquierdo, M.S., Fernández-Palacios, H., \& Tacon, A.G.J. (2001). Effect of broodstock nutrition on reproductive performance of fish. Aquaculture, 197, 25-42.

Jimenez-martinez, L.D., Alvarez-González, C.A., Tovar-Ramírez, D., Gaxiola, G., SanchezZamora, A., Moyano, F.J., Alarcón, F.J., Márquez-Couturier, G., Gisbert, E., Contreras- Sánchez, W.M., Perales-García, N., Arias-Rodríguez, L., Indy, J.R., Páramo-Delgadillo, S., \& PalominoAlbarrán, I.G. (2012). Digestive enzyme activities during early ontogeny in common snook (Centropomus Undecimalis). Fish Physiology Biochemistry, 38, 441-454.

Kuz'mina, V.V. (1996). Influence of age on digestive enzyme activity in some fresh water teleosts. Aquaculture, 148, 27-37.

Lazo, J.P., Mendoza, R., Holt, G.J., Aguilera, C., \& Arnold, C.R. (2007). Characterization of digestive enzymes during larval development of red drum (Sciaenops ocellatus). Aquaculture, 265, 194-205. http://doi.org/10.1016/j.aquaculture.2007.01.043 
Lojda, Z., Gossrau, R., \& Schiebler, T.H. (1979). Enzyme histochemistry: a laboratory manual.

Lovell, T. (1988). Nutrition and feeding of fish. Kluwer Academic Publishers (2nd ed.), Boston, Bordrecht, London.

Lupatsch, I., Deshev R., \& Magen, I. (2010). Energy and protein demands for optimal egg production including maintenance requirements of female tilapia Oreochromis niloticus. Aquaculture, 41(5): 763-769.

Ma, H., Cahu, C., Zambonino-Infante, J., Yu, H., Duan, Q., Le Gall, M.-M., \& Mai, K. (2005). Activities of selected digestive enzymes during larval development of large yellow croaker (Pseudosciaena crocea). Aquaculture 245, 239-248.

Martínez, I., Moyano, F.J., Fernández-Díaz, C., \& Yúfera, M. (1999). Digestive enzyme activity during larval development of the senegal sole (Solea senegalensis). Fish Physiology and Biochemistry 21, 317-323.

Maroux, S., Louvard, D., \& J, Baratti. (1973). The aminopetidase from hog intestinal brush border. Biochemistry Biophysiology Acta, 321, 282-295.

Métais, P. \& Bieth, J. (1968). Détermination de l' $\alpha$-amylase. Annalytical and Biology Chemistry, $26,133-142$.

Moyano, F.J., M. Diaz, F.J. Alarcon, and M.C. Saraqueste. (1996). Characterization of digestive enzyme activity during larval development of gilthead seabream Spaurus aurata. Fish Physiology and Biochemistry, 15, 121-130

Mylonas, C.C. and Y. Zohar. (2007). Promoting Oocyte Maturation, Ovulating And Spawing In Farmed Fish. In The Fish Oocyte, 437-474.

Nazemroaya, S., Yazdanparast, R., Nematollahi, M.A., Farahmand, H., \& Mirzadeh, Q. (2015). Ontogenetic development of digestive enzymes in sobaity sea bream Sparidentex hasta larvae under culture condition. Aquaculture, 448, 545-551. http://doi.org/10.1016/j.aquaculture.2015.06.038. 
Nelson, D.L. \& Cox, M.M. (2014). Princípios de Bioquímca de Lehninger. (6nd ed). New York: artmed.

Ohkubo, N., Sawaguchi, S., Nomura, K., Tanaka, H., \& Matsubara, T. (2008). Utilization of free amino acids, yolk protein and lipids in developing eggs and yolk-sac larvae of Japanese eel Anguilla japonica. Aquaculture 282, 130-137.

Oozeki, Y. \& Bailey, K.M. (1995). Ontogenetic development of digestive enzyme activities in larval walleye pollock, Theragra chalcogramma. Marine Biology, 122, 177-186.

Oliveira, M.M., Ribeiro, T., Orlando, T.M., Oliveira, D.G.S., Drumond, M.M., Freitas, R.T.F., \& Rosa, P.V. (2014). Effects crude protein levels on female nile tilapia (Oreochromis niloticus) reproductive performance. Animal Reproduction Science, 150(1-2): 62-69.

Oliveira, M.M., Ferreira, M.R., Goulart, M.B., Felizardo, V.O., Murgas, L.D.S., Andrade, E.S., Allaman, I.B., Veras, G.C., Costa, D.V., \& Rosa, P.V. (2015). Effect crude protein levels on the broodstock spermatic quality of Nile tilapia (Oreochromis niloticus). American Journal of Experimental Agriculture, 5(3): 192-199.

Portella, M.C., Leitão, N.J., Takata, R., \& Lopes, T.S. (2012). Alimentação e Nutrição de larvas. Nutriaqua - Nutrição e alimentação de espécies de interesse para a aquicultura brasileira. Ministério da Pesca e Aquicultura, Brasil.

Pradhan, P.K., Jena, J., Mitra, G., Soad, N., \& Gisbert, E. (2013). Ontogeny of the digestive enzymes in butter catfish Ompokbi maculatus (Bloch) larvae. Aquaculture, 372-375, 62-69. http://doi.org/10.1016/j.aquaculture.2012.10.024

Solovyev, M., \& Gisbert, E. (2016). Influence of time, storage temperature and freeze/thaw cycles on the activity of digestive enzymes from gilthead sea bream (Sparus aurata). Fish Physiology Biochemistry, 42, 1383-1394.

Teixeira, E.A., Crepaldi, D.V., Faria, P.M.C., Ribeiro, L.P., Melo, D.C., \& Castro, A.C. (2008). Composição corporal e exigências nutricionais de aminoácidos para alevinos de tilápia (Oreochromis sp.). Revista Brasileira de Saúde e Produção Animal, 9, 239-246. 
Tong, X.H., Xu, S., \& Liu, H. (2013). Stages of embryonic development and changes in enzyme activities in embryogenesis of turbot (Scophthalmus maximus l.). Aquaculture International, 21, 129-142. http://doi.org/10.1007/S10499-012-9540-6

Tonga, X., Yang, X., Baob, C., Tang, X., Wang, J., Zhoub, Y., Tang, M. (2017). Ontogeny of the digestive enzymes, thyroid hormones and cortisol in developing embryos and yolk-sac larvae of turbot (Scophthalmus maximus L.). Aquaculture, $479, \quad 704 \quad-711$. http://doi.org/10.1016/j.aquaculture.2017.07.004

Worthington Biochemical Corporation. (1972). Worthington enzyme manual: enzymes, enzymes reagents, related biochemicals. Freehold, N.J.

Zambonino-Infante, J.L. \& Cahu, C. (1994). Development and response to a diet change of some digestive enzymes in sea bass (Dicentrarchus labrax) larvae. Fish Physiology and Biochemistry, 12 , 399-408.

Zambonino-Infante, J., \& Cahu, C. (2001). Ontogeny of the gastrointestinal tract of marine fish larvae. Comparative Biochemistry Physiology. C 130, 477-487.

Zambonino-Infante, J.L., \& Cahu, C.L. (2007). Dietary modulation of some digestive enzymes and metabolic processes in developing marine fish: applications to diet formulation. Aquaculture 268, $98-105$ 
TABLE 1 Ingredients of the experimental feed offered to the Nile tilapia broodfish during the experiment

\begin{tabular}{|c|c|c|}
\hline \multirow[b]{2}{*}{ Ingredients (96) } & \multicolumn{2}{|l|}{ Diets } \\
\hline & $\mathrm{T1}$ & $\mathrm{T} 2$ \\
\hline Feather meal & 1.00 & 1.50 \\
\hline Viscera meal & 11.00 & 12.00 \\
\hline Soy protein concentrate & 20.00 & 24.00 \\
\hline Corn Gluten Meal & 2.00 & 3.00 \\
\hline Wheat meal & 8.77 & 8.20 \\
\hline Wheat flour & 0.00 & 1.00 \\
\hline Macrogard" & 0.03 & 0.03 \\
\hline Active $\mathrm{MOS}^{\circ}$ & 0.50 & 0.50 \\
\hline Broken rice & 34.75 & 27.06 \\
\hline Meat and Bone Meal & 2.06 & 4.00 \\
\hline Fish meal & 10.00 & 12.00 \\
\hline Blood Meal & 1.50 & 2.00 \\
\hline Salt & 0.30 & 0.30 \\
\hline Dicalcium phosphate & 1.50 & 0.89 \\
\hline Fish oil & 4.00 & 1.00 \\
\hline Vitamin C monophosphate & 0.48 & 0.17 \\
\hline Choline Chloride & 0.20 & 0.20 \\
\hline L-Lysine & 0.10 & 0.20 \\
\hline L-Threonine & 0.12 & 0.20 \\
\hline Taurine & 0.10 & 0.10 \\
\hline Dc-Methionine & 0.24 & 0.40 \\
\hline Antioxidant & 0.10 & 0.10 \\
\hline Mycotoxin adsorbent & 0.20 & 0.20 \\
\hline Fungistatic ${ }^{d}$ & 0.30 & 0.20 \\
\hline Orego-Stim* & 0.05 & 0.05 \\
\hline Vit. and Min. Supplement ${ }^{*}$ & 0.70 & 0.70 \\
\hline Total & 100.00 & 100.00 \\
\hline
\end{tabular}

" $\beta$-Glucan (Biorigin").

"Mannan oligosaccharide (Biorigin").

'Oxinyl Dry.

"Fylax.

"Essential oils (Meriden Animal Health").

Vitamin and Mineral Supplement (In Vivo") - levels of guarantee per $\mathrm{kg}$ of the product: Vitamin A - $12.000 .00 \mathrm{IU} / \mathrm{kg}$; Vitamin D3 - 3.000.00 IU/kg; Vitamin E - $150.0 \mathrm{mg}$; Vitamin K3 - $15.00 \mathrm{mg}$; Vitamin B1 - $20.00 \mathrm{mg}$; Vitamin B2 $-20.00 \mathrm{mg}$; Vitamin B6 $-17.50 \mathrm{mg}$ : Vitamin B12 - $40.00 \mathrm{mcg}$; Vitamin C - $300.00 \mathrm{mg}$; Nicotinic Acid - $100.00 \mathrm{mg}$; Pantothenic Acid - $50.00 \mathrm{mg}$; Biotin - $1.00 \mathrm{mg}$; Folic

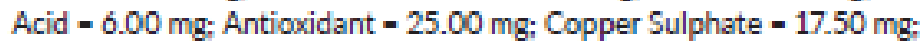
Iron Sulphate - 100.00 mg; Manganese Sulphate - 50.00 mg;

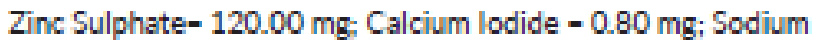

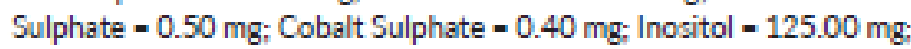
Choline -500.00 . 
TABLE 2 Centesimal composition of the experimental feed offered to the Nile tilapia broodfish during the experiment

\begin{tabular}{|c|c|c|}
\hline \multirow[b]{2}{*}{ Composition (\%) } & \multicolumn{2}{|l|}{ Diets } \\
\hline & T1 & $\mathrm{T} 2$ \\
\hline Humidity & 5.65 & 7.15 \\
\hline Crude protein & 32.21 & 38.34 \\
\hline Digestible Energy $y^{\mathbf{a}, \mathbf{b}}$ & $3,550.61$ & $3,454.79$ \\
\hline Digestible Protein" & 27.03 & 32.00 \\
\hline Ethereal Extract & 7.78 & 4.00 \\
\hline Crude Fiber & 2.40 & 2.57 \\
\hline Calcium & 2.69 & 3.13 \\
\hline Phosphorus & 1.50 & 1.63 \\
\hline Starch & 30.00 & 25.27 \\
\hline Arginine & 2.10 & 2.44 \\
\hline Lysine & 2.00 & 2.51 \\
\hline Methionine + Cysteine & 1.08 & 1.26 \\
\hline Threonine & 1.44 & 1.82 \\
\hline Tryptophan & 0.34 & 0.40 \\
\hline Methionine & 0.86 & 1.13 \\
\hline
\end{tabular}

-Calculated values.

${ }^{\mathrm{b}} \mathrm{Kcal}$. 

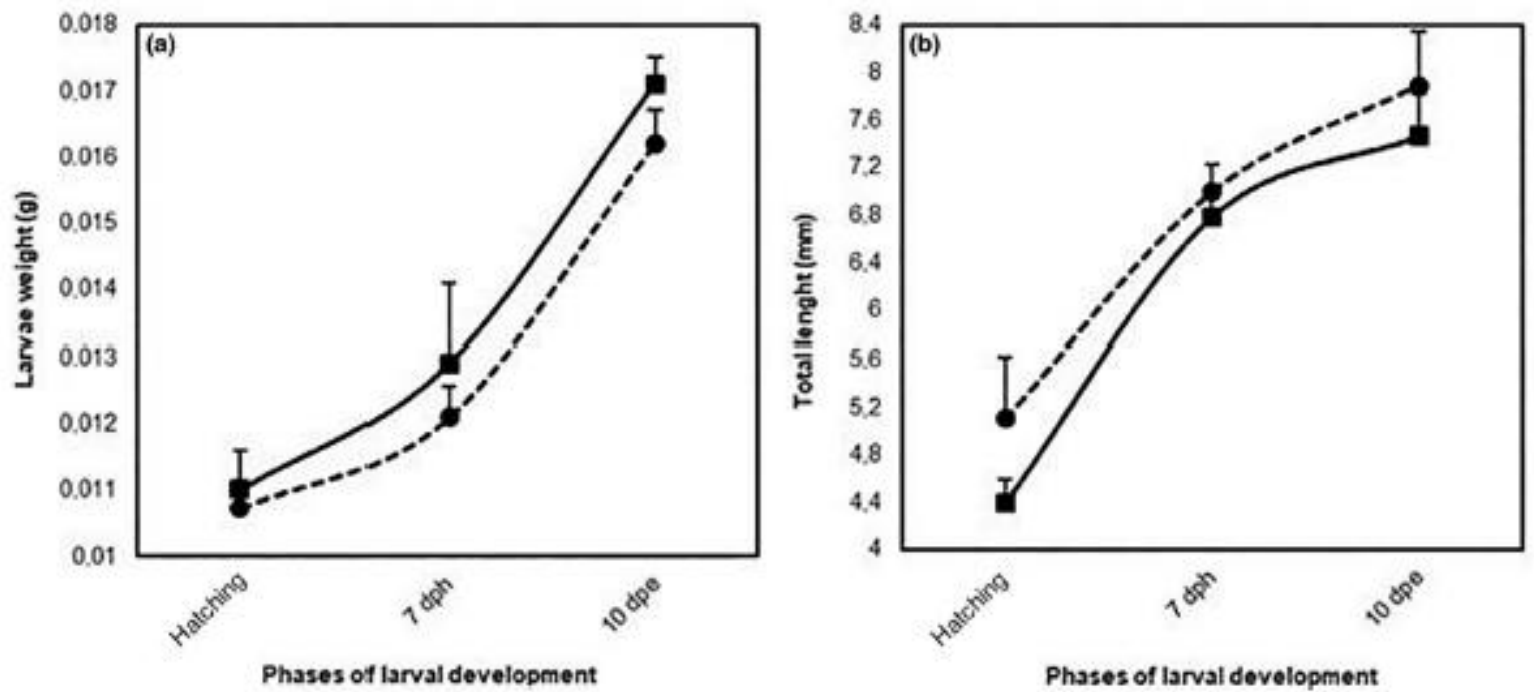

FIGURE 1 Weight (a) and length (b) on phases of larval development of Nile tilapia with breeders feed $32 \% \mathrm{CP}(\mathbf{m})$ and $38 \% \mathrm{CP}(\bullet)$. Letters superscript indicated statistically significant difference between crude protein level $(0.05)$ 


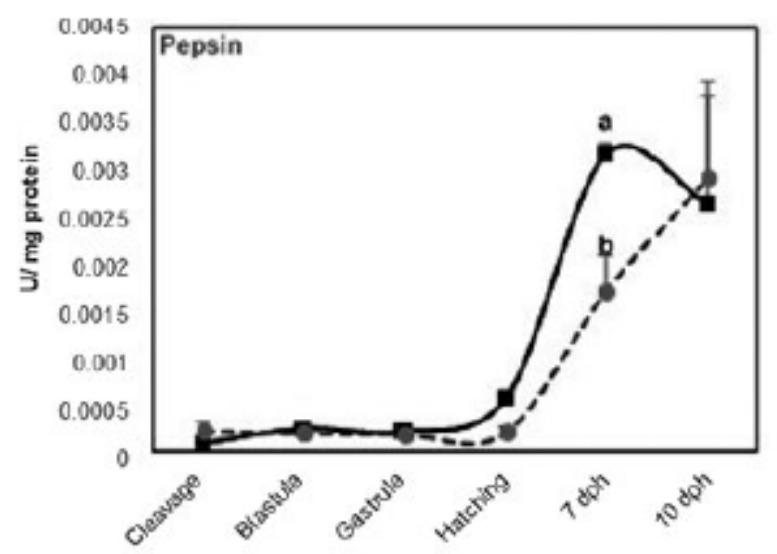

Phases of embryonic and lanal development

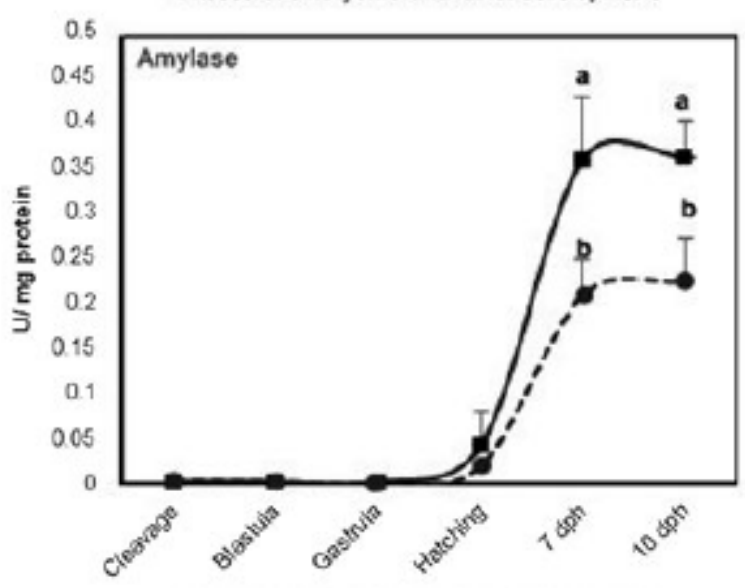

Phases of embryonic and larval development

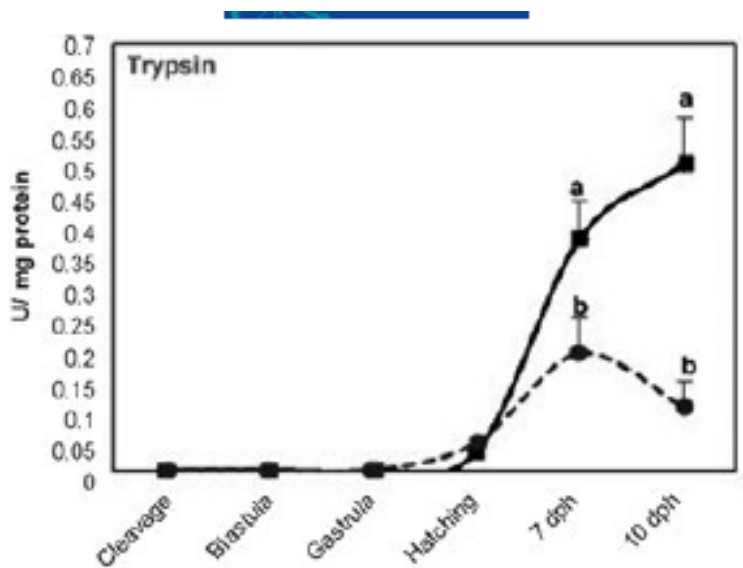

Phases of embryonic and larval development

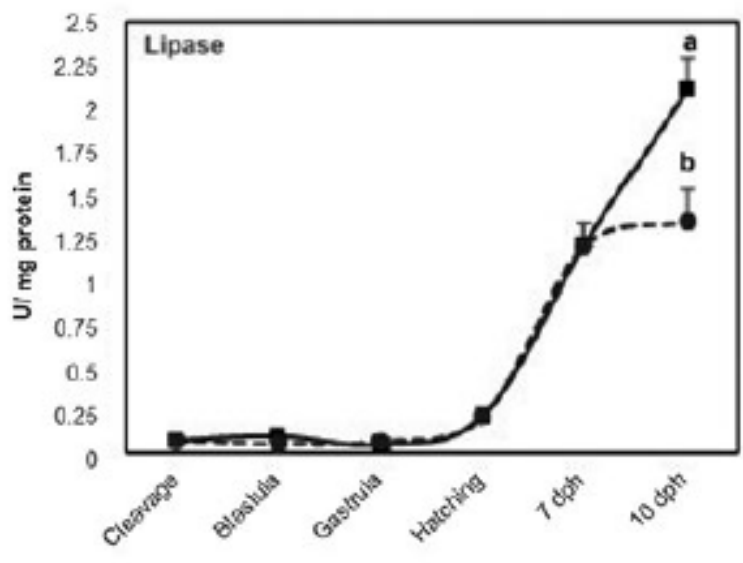

Phases of embryonic and tarval development

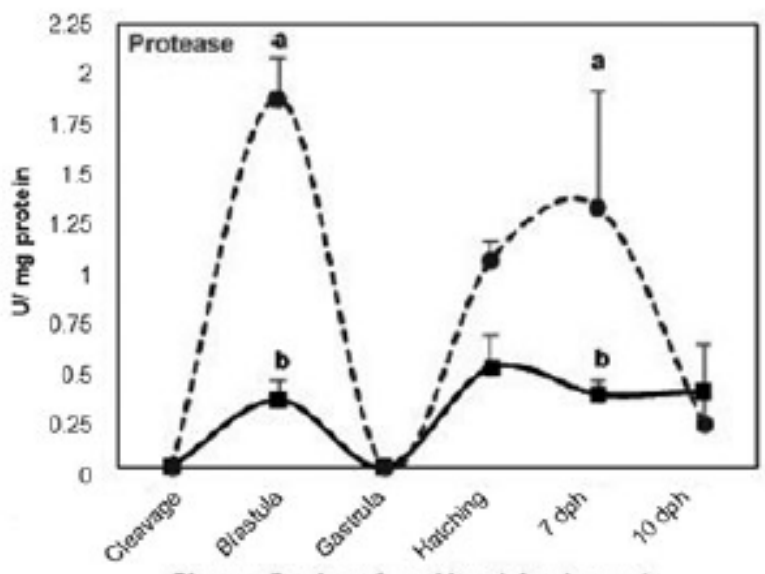

Phases of embryonic and larval devolopment

FIG URE 2 Activity (means \pm SD, n - 4) of gastric (acid proteases) and pancreatic enzymes (trypsin, amylase, lipase, protease) from Nile tilapia from cleavage to larval stage $(10 \mathrm{dph})$ with breeders feed with $32 \% \mathrm{CP}(\mathbf{m})$ and $38 \% \mathrm{CP}(\bullet)$. Letters superscript indicated statistically significant difference between crude protein level $(0.05)$ 

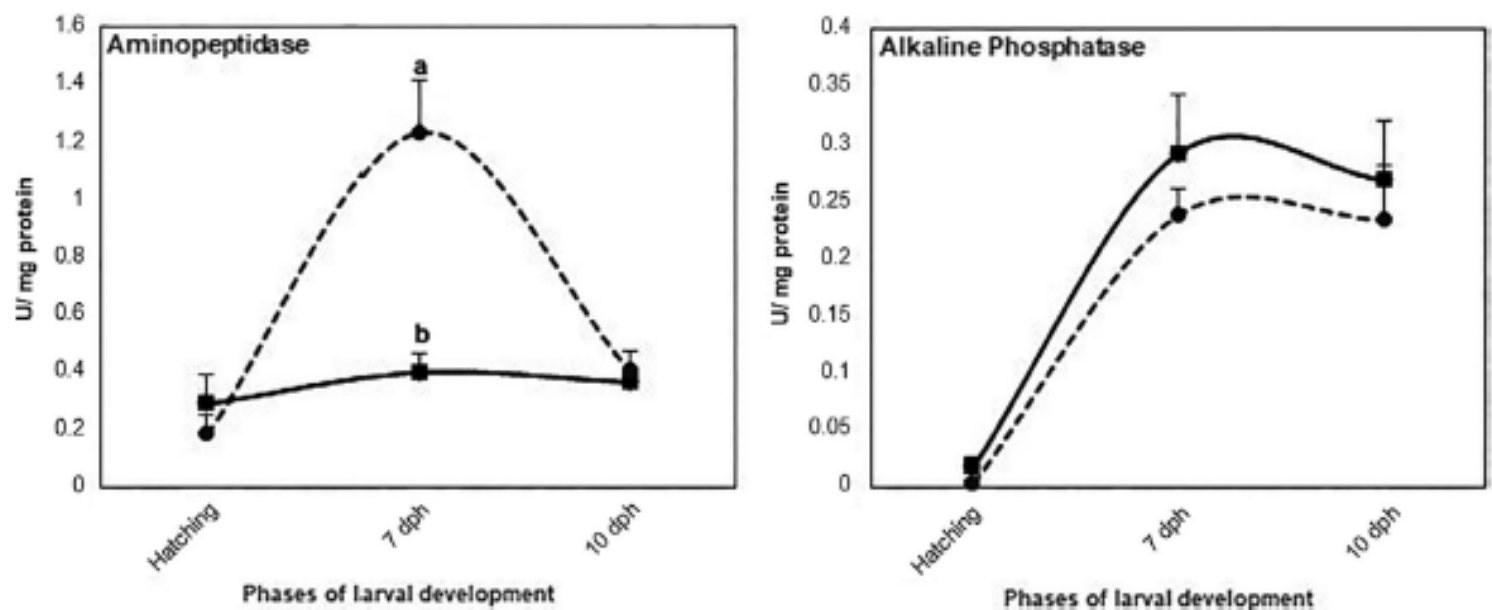

FIG URE 3 Activity (means \pm SD, $n-4$ ) of intestinal enzymes (aminopeptidase and alkaline phosphatase) from Nile tilapia from hatching to larval stage $(10 \mathrm{dph})$ with breeders feed $32 \% \mathrm{CP}(\mathbf{m})$ and $38 \% \mathrm{CP}(\bullet)$. Letters superscript indicated statistically significant difference between crude protein level $(0.05)$ 